\title{
Standardization of Minisett Technique in Greater yam (Dioscorea alata L.) Under Southern Rajasthan Conditions
}

\author{
Mithlesh Kumari Meena* and R. S. Rathore \\ Department of Horticulture, MPUAT, Udaipur 313001, India \\ *Corresponding author
}

Ke y w o r d s
$\begin{aligned} & \text { Dioscorea alata, } \\ & \text { Minisett, Tuber } \\ & \text { yield, Anthocyanine }\end{aligned}$
Article Info
Accepted:
15 February 2020
Available Online:
10 March 2020

\section{A B S T R A C T}

Dioscorea alata is one of the yam species commonly known as purple yam, winged or water yam. It has high beneficial value due to high nutrition and contains anthocyanin pigment which can be extracted as food colourant. In yam plantations, farmers required to set aside $33 \%$ of their harvest as planting materials. To solve this problem, minisett technique was practiced to produce large number of healthy seed yams. The presented investigation entitled "Standardization of minisett technique in greater yam (Dioscorea alata L.) Under Southern Rajasthan Conditions" was conducted at Horticulture Farm, Department of Horticulture, Rajasthan College of Agriculture (MPUA\&T) Udaipur, Rajasthan (India) during June 2017 to March 2018. The experiment was laid out in Randomized Block Design with three replications. Result showed that the growth parameters of greater yam were significantly $(\mathrm{p}=0.05)$ affected by minisett technique. Heaviest weight $(250 \mathrm{~g})$ of tubers shows the maximum no. of leaves $(90.00)$, maximum leaf area per vine $\left(8181.76 \mathrm{~cm}^{2}\right)$. The different size of tubers significantly $(\mathrm{p}=0.05)$ affect the yield parameters of yam. Yield parameters like no. of tubers per vine (3.33), length of tuber $(18.18 \mathrm{~cm})$, girth of tuber $(9.99 \mathrm{~cm})$, tuber yield $(1.97 \mathrm{~kg})$ per vine were found maximum in $200 \mathrm{~g}$ weight of tubers. The quality parameters like anthocyanin content do not showed any $\mathrm{m}$ significant influence by various tuber weight in greater yam.

\section{Introduction}

Yam belongs to genus Dioscorea which contains about 600 species (Coursey, 1967). Greater yam is one of important yam species, which is known as purple yam, winged yam or water yam. Greater yam is the third global agro-economic product after cassava and sweet potato (Harijono, 2013). Greater yam (Dioscorea alata L.) belongs to the family Dioscoreaceae and it has chromosome number $(2 n=2 x=20 \& 2 n=4 x=40)$. It contains anthocyanin pigment in its bright lavender colour tuber which can be extracted as food colourant (Jose et al., 2015). It is a very nutritive vegetable and contains starch (27.88 $\mathrm{g})$, energy $(108 \mathrm{kcal})$, vitamin A $(138 \mu \mathrm{g})$ protein $(1.53 \mathrm{~g})$ and fibre $(0.65-1.40 \%)$ per $100 \mathrm{~g}$ of edible part. Ratalu widely used for making vegetable, chips, puri and fried vegetable for canning, dehydration and flour manufacture. 
The main constraints in cultivation of greater yam are lack of availability of healthy planting materials and low multiplication ratio i.e.1:6, therefore, released varieties take a long time to reach to the farmer. Traditionally, water yams are propagated vegetatively by means of tuber. Whole tuber called "seed" yam from $100 \mathrm{~g}$ to $1500 \mathrm{~g}$ are used as planting materials. Alternatively, larger tubers are often cut into approximately $200 \mathrm{~g}$ pieces and used to establish the new crops (Onwueme, 1978; Okoli et al., 1982). The sets are planted in one hectare area required about 18-20 qt. setts. Farmers must set aside 10 to 30 percent of their harvest as planting material (Wilson, 1989). This means large quantities of greater yam are required for propagation purpose and marketable tubers are reserved for planting. The cost of planting materials is over 33 percent of the total outlay for yam production, so there is a need to improve the rate of yam multiplication (Okoli and Akorada, 1995).

Soon, they discovered the minisett technique where yam can be cultivated even with a very small size of tuber (Eyitayo et al., 2010). The minisett technique is a unique technique and fulfills the need. It was developed by National Root Crops Research Institute (NRCRI), Nigeria. The technique involves cutting the selected "mother seed" yam into pieces $20 \mathrm{~g}$ to $25 \mathrm{~g}$ each, treating them in a fungicides or insecticides suspension and sprouting them in nursery beds or polyethylene bags. After three to four weeks, the sprouted minisetts are transplanted into the main fields [Vernier, 1991]. The main aim of minisett technique is not to produce large tuber but to produce large number of healthy planting seed yams. The minisett technique is profitable due to lower materials cost and higher yield (Eyitayo et al., 2010). It enhance the multiplication ratio $(1: 24)$ to large extent. Buds are spread all over the periderm (body surface) of yam tuber. Hence any portion of yam tuber having is capability to sprouting and producing a new plant (George et al., 2004). It is an effective and viable technology which is quite farmer friendly and farmers oriented. This technique presents a rapid and cheap multiplication method for greater yam and produced healthy greater yams. It also offers a chance to reduce the production cost of greater yam. The seed yam preferred for its earlier and more reliable sprouts; also it usually matures earlier than other types of seed species (IITA, 1993 b; Hahm et al., 1987). Therefore, in this study "Standardization of minisett technique in greater yam (Dioscorea alata L.) Under Southern Rajasthan Conditions" were investigated.

\section{Materials and Methods}

An experiment entitled "Standardization of minisett technique in greater yam (Dioscorea alata L.) Under Southern Rajasthan Conditions." was conducted at Horticulture farm, Department of Horticulture, Rajasthan College of Agriculture, Maharana Pratap University of Agriculture and Technology, Udaipur which is situated at South Eastern part of Rajasthan. This region falls under agro-climatic Zone IV a i.e. "South-humid Southern Plain and Aravalli Hills" of Rajasthan at altitude of 582.17 meter above mean sea level, $24^{\circ} 35^{\prime}$ latitude and $74^{\circ} 42^{\prime} \mathrm{E}$ longitude. This region has a typical subtropical climate, characterized by mild winters and summers. The average rainfall of this tract ranges from $592.5 \mathrm{~mm}$ to $620 \mathrm{~mm}$ per year. More than 90 per cent of rainfall is received during mid-June to September with scanty showers during winter months. The experiment was laid out with Randomized Block Design with ten treatments and three replications.

\section{Preparation of samples and field}

In minisett technique, mother seed yam of 500-1000g that have broken dormancy are cut into pieces weighed of $25 \mathrm{~g}, 50 \mathrm{~g}, 75 \mathrm{~g}, 100 \mathrm{~g}$, 
$125 \mathrm{~g}, 150 \mathrm{~g}, 175 \mathrm{~g}, 200 \mathrm{~g}, 225 \mathrm{~g}, 250 \mathrm{~g}$, with the help of sharp knife and tubers were treated with fungicide $(12 \%$ carbendazim $+63 \%$ mencozeb). The tubers from each treatment were sown in pots filled with moist growing media containing $75 \%$ soil $+25 \%$ FYM. The pots watered regularly. The experimental field prepared with one ploughing with a mould board plough in the followed by cross harrowing with disc cultivator and finally by planking. Basal application of well rotten FYM@ 3 tons ha ${ }^{-1}$ was incorporated in field before transplanting. The layout of experiment was prepared as per treatments and replications. Yam seedlings were ready for transplanting 2 months after sowing of tubers. Seedling were planted at $7.5 \mathrm{~cm}$ depth keeping $90 \times 90 \mathrm{~cm}$ spacing and covered with soil. Irrigation may be given at weekly intervals in the initial stage and afterwards at about 10 day interval. Bamboo poles were used as staking material to support the trailing vines. Initially the vines were tied with the coir string. The crop was harvested manually 8 months after planting. The crop was harvested at full physiological maturity stage. A light irrigation 2-3 days before harvesting was required. Vines were removed first and then tubers were dug out manually with proper care. Cleaning was done to remove adhered roots and soil particles.

\section{Data collected include}

In this experiment, observation were collected growth parameters like no. of leaves, leaf area per vine; yield parameters like no. of tubers per vine length of tuber, girth of tuber, tuber yield $(\mathrm{kg})$ per vine and quality parameter like anthocyanin content $(\mathrm{mg} / 100 \mathrm{~g})$.

Anthocyanin is intensely coloured water soluble pigments are responsible for nearly all colours in leaves, petals and fruits of higher plants. Extraction of anthocyanin is based on the principle are the alcohol extract of sample is treated with $\mathrm{HCl}$ in aqueous methanol followed by anthocyanin reagent. The colour intensity is measure colorimetrically at $525 \mathrm{~nm}$. The experimental data were subjected to statistical analysis of variance and test of significance through the procedure appropriate to the Randomized Block Design as described by Panse and Sukhatme (1989) and means differences determined by L.S.D. at $5 \%$ level of significance.

\section{Results and Discussion}

\section{Growth parameters}

The results showed (Table-1) significant differences $(\mathrm{P}=0.05)$ among the different set of minisetts of greater yam in no. of leaves per vine, leaf area $\left(\mathrm{cm}^{2}\right)$. There were gradually increase in no. of leaves per vine, leaf area $\left(\mathrm{cm}^{2}\right)$ as the size of yam increased throughout the samples. The maximum leaves per vine (96.00) was recorded in T10 (250g) followed by 92.67 in $\mathrm{T} 8(200 \mathrm{~g})$ and minimum leaves per vine (51.00) was recorded in $\mathrm{T} 1$ $(25 \mathrm{~g})$. The present finding also supported with Onwuaeme (1972), Asadu et al., (1987) and Cyansa- Ameyaw et al., (1991), Okonmah and Akparobi, (2009), Ch'ng et al., (2017) are reported that larger setts are quickly established and more vigorous as compared to small weight of seed yam and promote vegetative growth parameters such as number of leaves.

The maximum leaf area $\left(8181.76 \mathrm{~cm}^{2}\right)$ was recorded in T10 (250g) followed by 7281.39 $\mathrm{cm}^{2}$ in treatment T8 $(200 \mathrm{~g})$ and minimum leaf area $\left(2900.89 \mathrm{~cm}^{2}\right)$ was recorded in treatment T1 (25g). Leaf area index and leaf area duration increased with an increase in seed size (Enyi, 1972). The maximum node bits produced more leaf area, roots and root length in kasturi turmeric (Aswathy and Jessykutty, 2017). 
Table.1 Effect of minisett on leaves per vine, leaf area $\left(\mathrm{cm}^{2}\right)$ after 4 months

\begin{tabular}{|c|c|c|}
\hline Treatments & Leaves per vine & Leaf area $\left.\mathbf{( c m}^{\mathbf{2}}\right)$ \\
\hline $\mathbf{T}_{\mathbf{1}}$ & 51.00 & 2900.89 \\
\hline $\mathbf{T}$ & 52.57 & 2960.68 \\
\hline $\mathbf{T 3}$ & 52.97 & 3491.62 \\
\hline $\mathbf{T} 4$ & 53.00 & 3593.58 \\
\hline $\mathbf{T} 5$ & 54.27 & 3631.32 \\
\hline $\mathbf{T 6}$ & 59.67 & 4454.17 \\
\hline $\mathbf{T} 7$ & 53.53 & 3566.77 \\
\hline $\mathbf{T 8}$ & 92.67 & 7281.39 \\
\hline $\mathbf{T} 9$ & 65.47 & 5143.12 \\
\hline $\mathbf{T 1 0}$ & 96.00 & $\mathbf{8 1 8 1 . 7 6}$ \\
\hline $\mathbf{S E m} \pm$ & $\mathbf{1 . 3 1}$ & $\mathbf{1 3 4 . 5 0}$ \\
\hline $\mathbf{C D}(\mathbf{P}=\mathbf{0 . 0 5})$ & $\mathbf{3 . 8 6}$ & $\mathbf{3 9 9 . 6 2}$ \\
\hline $\mathbf{C V}(\mathbf{\%})$ & 6.2 & 8.9 \\
\hline
\end{tabular}

Table.2 Effect of minisett on number of tubers per vine, tuber length $(\mathrm{cm})$ tuber diameter $(\mathrm{cm})$ and tuber yield $(\mathrm{kg})$

\begin{tabular}{|c|c|c|c|c|c|}
\hline Treatments & $\begin{array}{c}\text { Tubers per } \\
\text { vine }\end{array}$ & $\begin{array}{c}\text { Tuber length } \\
(\mathbf{c m})\end{array}$ & $\begin{array}{c}\text { Tuber diameter } \\
(\mathbf{c m})\end{array}$ & $\begin{array}{c}\text { Tuber yield } \\
(\mathbf{k g}) \text { per vine }\end{array}$ & $\begin{array}{c}\text { Anthocyanin } \\
\text { (mg/100g) }\end{array}$ \\
\hline T & 1.37 & 12.74 & 4.95 & 0.86 & 1.08 \\
\hline T2 & 1.77 & 12.92 & 5.20 & 0.87 & 1.19 \\
\hline T3 & 1.90 & 14.30 & 5.42 & 0.89 & 1.22 \\
\hline T4 & 2.07 & 14.56 & 5.79 & 1.11 & 1.13 \\
\hline T5 & 2.17 & 14.08 & 6.13 & 1.27 & 1.14 \\
\hline T6 & 2.63 & 16.41 & 7.54 & 1.42 & 1.40 \\
\hline T7 & 2.63 & 16.83 & 7.64 & 1.43 & 1.35 \\
\hline T8 & $\mathbf{3 . 3 3}$ & $\mathbf{1 8 . 1 8}$ & $\mathbf{9 . 9 9}$ & $\mathbf{1 . 9 7}$ & 1.37 \\
\hline T9 & 3.27 & 17.53 & 8.50 & 1.94 & 1.35 \\
\hline T10 & 3.10 & 17.47 & 7.78 & 1.94 & 1.36 \\
\hline SEm \pm & $\mathbf{0 . 1 0}$ & $\mathbf{0 . 4 1}$ & $\mathbf{0 . 3 2}$ & $\mathbf{0 . 0 2}$ & $\mathbf{0 . 0 5}$ \\
\hline CD (P=0.05) & $\mathbf{0 . 3 1}$ & $\mathbf{1 . 2 2}$ & $\mathbf{0 . 9 4}$ & $\mathbf{0 . 0 7}$ & $\mathbf{N S}$ \\
\hline CV $(\mathbf{\%})$ & 12.8 & 7.9 & 13.8 & 5.2 & 11.9 \\
\hline
\end{tabular}

\section{Yield and quality traits}

The data reported (Table 2) revealed that the no. tubers per vine, tuber length, tuber diameter, tuber yield $(\mathrm{kg})$ per vine were significantly influenced by minisetts of greater yam and the yield parameters are increased as increased size of tubers as sample. There were no significant difference
$(\mathrm{P}<0.05)$ between tubers size of $200 \mathrm{~g}, 225 \mathrm{~g}$, $250 \mathrm{~g}$ but they are significantly higher other tuber size viz. $25 \mathrm{~g}, 50 \mathrm{~g}, 75 \mathrm{~g}, 100 \mathrm{~g}, 125 \mathrm{~g}$, $150 \mathrm{~g}, 175 \mathrm{~g}$.

The maximum number of tuber per vine (3.33) was recorded in T8 (200g) followed by $3.27,3.10$ in $\mathrm{T} 9 \quad(225 \mathrm{~g}) \& \mathrm{~T} 10 \quad(250 \mathrm{~g})$ respectively and minimum number of tuber 
per vine (1.37) was recorded in $\mathrm{T} 1(25 \mathrm{~g})$. The maximum tuber length $(18.18 \mathrm{~cm})$, tuber diameter $(9.99 \mathrm{~cm}) \&$ tuber yield $(1.97 \mathrm{~kg})$ per vine were recorded in $\mathrm{T} 8(200 \mathrm{~g})$ and minimum tuber length $(12.74 \mathrm{~cm})$ tuber diameter $(4.95 \mathrm{~cm}) \&$ tuber yield $(0.86 \mathrm{~kg})$ per

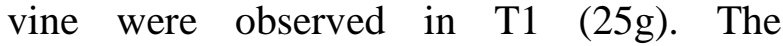
anthocyanin content (mg/100g) was not significantly influenced by various tuber weight. The highest anthocyanin content $(1.37 \mathrm{mg} / 100 \mathrm{~g})$ was recorded in treatment $\mathrm{T} 8$ (200g).

It might be due to increase in vegetative growth with maximum harvest of solar light. Further, bigger size of seed tuber, are directly positively correlated with vegetative growth parameters, which was one of the reasons for achieving higher yield of greater yam in $T_{8}$ (200g). Although tuber yield increased with increasing sett size and effect was confined to middle setts particularly at the wide spacing. Similarly, larger size tuber helps in development of new cells in meristematic tissue and regulates carbohydrate metabolism $\&$ also helps in formation of chlorophyll and absorption of other nutrients in soil and resulted more accumulation in sink. The above results are in conformity with the findings of Onwueme, (1972), Nwoke et al., (1973), Obigbesan, (1980), Kayode, (1984) and Okonmah and Akparobi, (2009) in greater yam.

This study concluded that the growth parameters like no. of leaves, leaf area and yield attributes like tuber yield per vine $(\mathrm{kg})$, tuber length $(\mathrm{cm})$, tuber diameter $(\mathrm{cm})$, number of tubers per vine and quality attributes like anthocyanin $(\mathrm{mg} / 100 \mathrm{~g})$ were recorded higher in large weight of tuber i.e., $200 \mathrm{~g}, 225 \mathrm{~g}$, and $250 \mathrm{~g}$ weight tuber.

\section{References}

Asadu, C.L.A., Ezeumah, H.C., Nweke, F.I. and Akammigbo, F.O.R. 1987. The performance of size cultivars of white yam derived from three sources and evaluated across three zones in southern Nigeria, In: "Linking similar environment", cassava based cropping system. Research I, Ibadan, Nigeria. 16-19 Nov., 1987, pp: 215-223.

Aswathy, T.S. and Jessykutty, P. C. 2017. Rapid multiplication of kasturi turmeric (Curcurma aromatic solisab.) through minisett technique and nursery management. Journal of Spices and Aromatic Crops, 26 (1): 47-50.

Ch'ng, H.Y., Yang, K.K.Y. and Othman, S.B.2017. Influence of minisett size of purple yam (Dioscorea alata L.) towards the seedling emergence and growth rate in production of seed yam. International Journal of Applied Research, 3(4): 367370.

Coursey, D.G. 1967. Yam on the account of the nature, origins, cultivation and utilization of the useful members of the discoreaceae, Longman, London, UK.

Cyansa- Ameyaw, C.E., Hahn, S.K., Alarez, M.M. and Doku, E.V. 1991. Determination of optimal sett size for white guinea yam (Dioscorea rotundata Poir.) seed yam production: Trends in sprouting in pre sprout nursery and field performance. In: Tropical root crops in developing economy Ofori, F., Hahn, S.K. (eds.), proceeding of the $9^{\text {th }}$ Symposium of the International Society of Tropical Root Crops, 20-26 October, 1991.

Enyi, B.A.C. 1972. Effect of seed size and spacing on growth and yield of lesser yam (Dioscorea esculenta). The Journal of Agricultural Science, 72(2): 215-225.

Eyitayo, O.A., Anthony, T.O., and Theresas, I. 2010. Economics of seed yam production using minisett technique in Oyo state, Nigeria. Field Actions Science Reports, 4(2): $1-5$.

George, J., Nair, S. S. and Sree Kumari, M. T. 2004. Rapid multiplication of quality planting material in tuber crops. pp: 30-33. Central Tuber Crops Research Institute, Sreekariyan, Kerela. 
Hahn, S.K., Osiru, D.S., Akoroda, M.O. and Otoo, J. A. 1987. Yam production and its future prospects. Out -look on Agriculture, 16(3):105-110.

Horijono, T. E. 2013. Physiochemical and bioactive characteristics of purple yam and yellow water yam (Dioscorea alata L.) tuber. International Journal of Pharma Tech Research, 5(4):1691-1701.

IITA,1993b. Yam improvement at IITA, Ibadan.

Jose, A, and Muhammed, R. 2015. Extraction and evaluation of anthocyanin from Dioscorea alata $\mathrm{L}$. for its application as a natural food colour. The International Journal of Science and Technologies, 3(9): 41-47.

Kayode,G.O. 1984. The effect of sett size and spacing on tuber yield of white guinea yam (Dioscorea rotundata) in rain forest and savana zones of Nigeria. Experimental Agriculture, 20(1):53-57.

Nwoke, F.I.O., Njoku, E. and Okonkwo, S.N.C. (1973). The effect of size of seed yams on yield of individual plants of Dioscorea rotundata. In: $3^{\text {rd }}$ International Symposium on Tropical Root Crops, Ibadan, Nigeria, 2-9 December 1973.

Obigbesan, G.O. 1980. Growth yield and quality of Chinese yam (Dioscorea esculanta) as affected by seed tuber size. In: $1^{\text {st }}$ Triennial Root Crops Symposium. ISRTC- Africa branch. 8-12 Sept. 1980. International Development Center, Ottawa, Canada.

Okoli, O.O., M.C. Igbokwe. 1982. Rapid multiplication of yam by minisett technique. Research Bulletin 2, N.R.C.R.I., Umudike. 12 p.
Okoli, O., Acha, L.A., Shiwachi, H., Asiedu R. and Akoroda M.O., 1982. Effect of auxin on root development in yam (Dioscorea rotundata) vine. Tropical Science. 44: 8084.

Okoli, O.O., and Akoroda, M.O. 1995. Providing seed tubers for the production of food yams. African Journal of Root and Tuber crops, 1(1): 1-6.

Okonmah, L.U. and Akparobi, S.O. 2009. Effect of seed yam weight on growth and tuber yield of white yam. Ghana Journal of Agricultural science, 42(1): 1-2.

Onwueme, I.C., 1972. Influence of the weight of planted tuber on the growth and performance of white yam (D. rotundata poir.) plants. Nigeria Agricultural Journal, 19(1): 170-173.

Onwueme, I.C., 1978. The tropical tuber crops, yams, cassava, sweet potato and cocoyam.14:234.

Panse, V.G. and Sukhatme, P.V. 1989. Statistical Method for Agricultural Works. ICAR, New Delhi.

Vernier, P., Ericas, N., Aegbo, E., Hounhouigan, J., N'Kpenu, K. and Orkwor G. From biological control to a systems approach in post- harvest. Proceedings of an IITA/GTZ meeting on integrated control of insect pests in rural maize stores, with particular reference to the Larger Grain Borer and the future development of the post-harvest sector in sub-Saharan Africa; 1999. 10

Wilson, J.E., 1989. Rapid multiplication of yams (Dioscorea spp.). Institute for Research, Extension and Training in Agriculture. 3(88): 1-11.

\section{How to cite this article:}

Mithlesh Kumari Meena and Rathore, R. S. 2020. Standardization of Minisett Technique in Greater yam (Dioscorea alata L.) Under Southern Rajasthan Conditions. Int.J.Curr.Microbiol.App.Sci. 9(03): 2355-2360. doi: https://doi.org/10.20546/ijcmas.2020.903.268 